\title{
Effect of Scour on the Natural Frequency Responses of the Meteorological Mast in the Taiwan Strait
}

\author{
Wei-Chen Tseng ${ }^{1}$, Yu-Shu Kuo ${ }^{2, *}$, Kung-Chun Lu ${ }^{3}$, Jing-Wen Chen ${ }^{1}$, Chiou-Fong Chung ${ }^{4}$ and \\ Ruey-Chyi Chen ${ }^{4}$ \\ 1 Department of Civil Engineering, National Cheng Kung University, Tainan 701, Taiwan; \\ weichen19841023@gmail.com (W.-C.T.); geochen@mail.ncku.edu.tw (J.-W.C.) \\ 2 Department of Hydraulic and Ocean Engineering, National Cheng Kung University, Tainan 701, Taiwan \\ 3 Structure Control Division, National Center for Research on Earthquake Engineering, Taipei 106, Taiwan; \\ kclu@narlabs.org.tw \\ 4 Taiwan Power Research Institute, Taiwan Power Company, Taipei 100, Taiwan; \\ u555348@taipower.com.tw (C.-F.C.); u630513@taipower.com.tw (R.-C.C.) \\ * Correspondence: kuoyushu@mail.ncku.edu.tw; Tel.: +886-6-275-7575 (ext. 63271)
}

Received: 12 February 2018; Accepted: 2 April 2018; Published: 3 April 2018

\begin{abstract}
The meteorological mast (met mast) for the Taiwan Power Company's offshore wind farm is located in Taiwan Strait near Changhua County. The $p-y$ curve method recommended in the current offshore foundation design codes does not account for the local scour around the pile foundation; it overestimates the lateral pile deformation and underestimates the foundation stiffness. This paper presents a method to correct the initial modulus of subgrade reaction and modify the ultimate lateral resistance caused by the local scour. The natural frequency of the met mast structure is also determined by a numerical model and verified with the measured data in situ. A comprehensive parameter study is performed to analyze the effect of scour on the dynamic responses of the met mast. Two types of foundation model, a coupled-springs foundation model and a distributed-springs foundation model, are considered in the dynamic analysis of the met mast. The results demonstrate that using a distributed-springs foundation model provides a relatively accurate estimate of the natural frequencies of the met mast structure. Furthermore, the scour exerted significant effects on certain modes of the vibration responses. The natural frequencies of the met mast structure can be reduced by approximately $14 \%$ due to scour, particularly in the horizontal bending modes. This paper also provides a preliminary strategy for structural monitoring and analysis to detect scour damage on offshore wind turbines with monopile foundations.
\end{abstract}

Keywords: meteorological mast; monopile; scour; foundation stiffness; natural frequency

\section{Introduction}

The dynamic behavior of the foundation must be considered in the design procedure of structures required to withstand dynamic loads. The dynamic loads exerted on offshore wind turbines include external environmental loads from winds, waves, currents, and seismic activity as well as internal mechanical vibrations. Therefore, determining the natural frequencies of the support structure is particularly important [1]. The resonance effects when the load frequencies are in or near the first natural frequency of the support structure can result in excessive deformation or collapse of the support structure. To prevent resonance, the first natural frequency of the support structure must not be close to the frequencies of the external dynamic loads and the internal mechanical vibrations [2-4].

The natural frequency of an offshore wind turbine support structure is affected by its geometry, weight distribution, and foundation stiffness. The foundation stiffness is determined by the 
load-deformation response of the foundation. However, the deformation moduli (shear and elastic moduli) of the soil surrounding the foundation decrease with the shear strain. Therefore, the load-deformation response of the foundation is non-linear. When an offshore wind turbine is in operation and experiences typical wind and wave loads, Det Norske Veritas (DNV) [1] recommends that the shear strain $\gamma$ of the soil surrounding the foundation must be less than $10^{-3}$, such that the foundation stiffness can be calculated using the initial slope of the load-deformation curve [5-7].

The $p-y$ curve method recommended in American Petroleum Institute (API) [8] and DNV Germanischer Lloyd (DNV GL) [9] is the most common method used to analyze laterally loaded piles and calculate the deformation responses. The $p-y$ curves are derived from empirical regressions using piles with a diameter $D$ of less than $2 \mathrm{~m}$; thus, the $p-y$ curve method underestimates the pile deformation with a large diameter $(D>4 \mathrm{~m})$ [10]. Numerous researchers have proposed corrections to the $p-y$ curves to analyze the load-deformation response in large-diameter monopile foundations [11-14].

The seabed in the vicinity of large-diameter $(D>4 \mathrm{~m})$ monopile foundations subjected to waves and currents can be scoured by horseshoe vortices [15-19]. DNV [20] and DNV GL [9] recommend a scour depth of 1 to 1.5 times the pile diameter for the monopile foundation design. The lateral displacement of piles increases with scour depth due to decrease of embedded pile length. The foundation stiffness also decrease with the scour depth.

A typical $p-y$ curve method does not consider the geometric shape of the scour hole caused by the local scour. Therefore, the entire layer of soil above the bottom of the scour hole will be ignored. Several researchers have recommended alternate methods to calculate the ultimate lateral soil resistance subjected to scour [21-23].

Taiwan plans to construct $4 \mathrm{GW}$ offshore wind farms in the Taiwan Strait before 2025. Severe scour occurs around the offshore structure foundations because of the strong currents in the Taiwan Strait near Changhua County. Taiwan Power Company (TPC) erected a meteorological mast (met mast) in the area to develop the Chang-Bin offshore wind farm. TPC monitored the water depths in the vicinity of the monopile foundation of the met mast for 6 months after the installation. The seabed elevation continued to change even with the scour protection [24].

Taiwan's offshore wind farms are in the initial stages of development, and no vibration data of the support structures of the offshore wind turbines are available yet. This study collects accelerometer data from TPC's met mast [24]. Time frequency analysis and system identification are used to identify the natural frequencies of the met mast structure. A finite element model is used to simulate the dynamic response of the met mast and estimate the effect of scour on the natural frequencies of the met mast structure. The results of this study demonstrate the scour effect on the natural frequencies of offshore structure. This paper also show the feasibility of structure monitoring and analysis method to detect scour around the monopile foundations of offshore wind turbines.

\section{Met mast of TPC in the Chang-Bin offshore Wind Farm}

The TPC met mast is located at the Chang-Bin offshore wind farm (Universal Transverse Mercator (UTM) coordinates E176028, N2655320) (Figure 1). The Chang-Bin offshore wind farm is $35 \mathrm{~km}$ long and $7 \mathrm{~km}$ wide, with a water depth ranging from 15 to $40 \mathrm{~m}$. The distance from the coast is $8-15 \mathrm{~km}$. The met mast has a jacket-type tower with a monopile foundation. The top of the met mast is $92 \mathrm{~m}$ above mean water level (MWL). The platform is at a height of $19 \mathrm{~m}$ above MWL. The monopile foundation has a diameter of $3.8 \mathrm{~m}$. The pile wall thickness is $0.05 \mathrm{~m}$, and the embedded pile length is $36.35 \mathrm{~m}$. BH-01 (UTM coordinates E175290, N2656260) is a nearest borehole to the TPC met mast, and the distance between them is $1.2 \mathrm{~km}$. The seabed soil within $71.5 \mathrm{~m}$ of the mudline is layered sand. The effective internal friction angle of soil is $29.5-33^{\circ}$. The effective unit weight of soil is $8.5-9.6 \mathrm{kN} / \mathrm{m}^{3}$. Table 1 presents the simplified soil layers for simulation [25]. Table 2 and Figure 2 show the dimensions and other fundamental information about the met mast. 


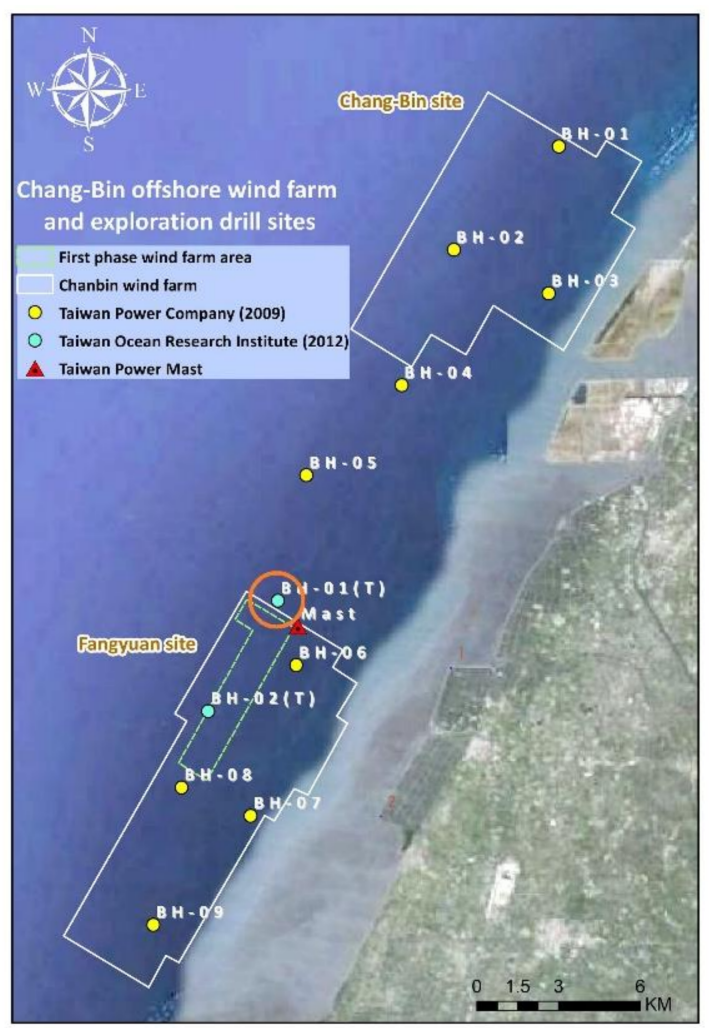

Figure 1. Taiwan Power Company's (TPC's) met mast and borehole site at Chang-Bin offshore wind farm.

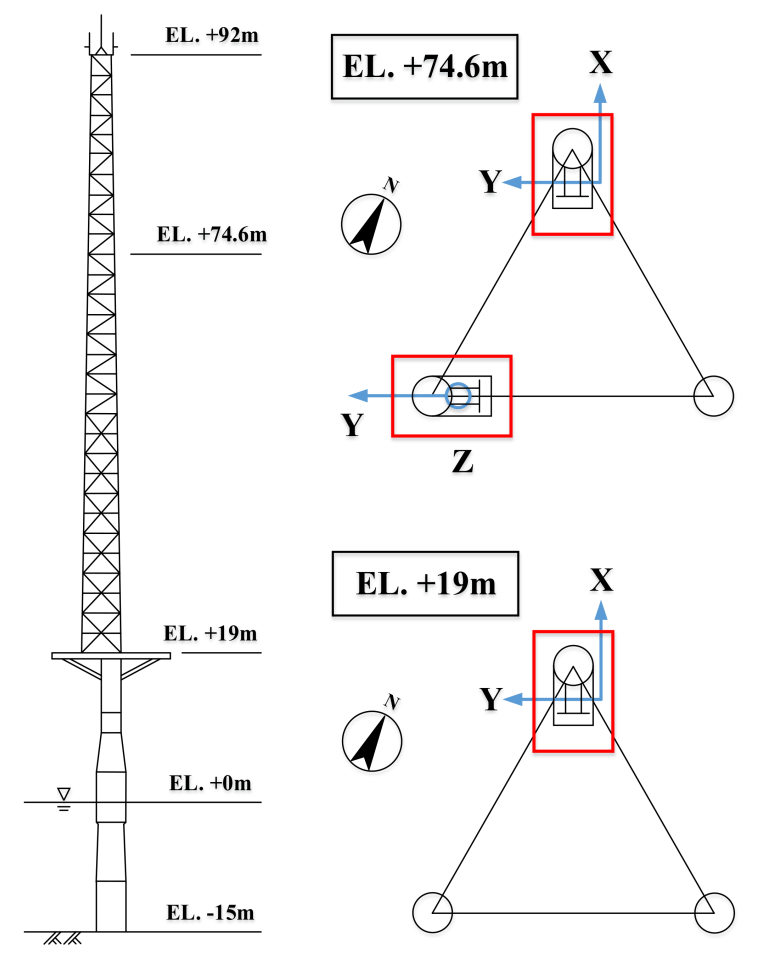

Figure 2. Schematic for TPC's met mast and the positions of accelerometers.

Two two-axis accelerometers oriented in the $\mathrm{X}-\mathrm{Y}$ and $\mathrm{Y}-\mathrm{Z}$ directions were installed on the met mast at a height of $74.6 \mathrm{~m}$ above the MWL. Another two-axis accelerometer $(X-Y)$ was installed at the height of the platform (19 $\mathrm{m}$ above the MWL) (Figure 2). The sampling frequency of the acceleration 
data was $100 \mathrm{~Hz}$. The resolution of the acceleration data was 0.1 gal. Twenty months of data were collected since May 2016.

Table 1. BH-01 simplified soil layers.

\begin{tabular}{cccc}
\hline Soil Layer & Depth $(\mathbf{m})$ & Effective Unit Weight $\mathbf{f l}^{\prime} \mathbf{( \mathbf { k N } / \mathbf { m } ^ { \mathbf { 3 } } )}$ & Friction Angle $\left.\boldsymbol{\phi}^{\prime} \mathbf{(}^{\mathbf{(}}\right)$ \\
\hline Sand 1 & $0-10.8$ & 8.5 & 29.5 \\
Sand 2 & $10.8-26.1$ & 9.5 & 32.0 \\
Sand 3 & $26.1-47.2$ & 9.6 & 32.3 \\
Sand 4 & $47.2-71.5$ & 9.5 & 33.0 \\
\hline
\end{tabular}

Table 2. Dimensions of TPC's met mast. MWL: mean water level.

\begin{tabular}{ccc}
\hline Geometry of Met-Mast & & Value \\
\hline Tower height above MWL & $(\mathrm{m})$ & 92 \\
Platform height above MWL & $(\mathrm{m})$ & 19 \\
Tower mass & $(\mathrm{ton})$ & 216 \\
Water depth & $(\mathrm{m})$ & 15 \\
Pile diameter & $(\mathrm{m})$ & 3.8 \\
Pile thickness & $(\mathrm{m})$ & 0.05 \\
Embedded pile length & $(\mathrm{m})$ & 36.35 \\
\hline
\end{tabular}

\section{Vibration Measurements and Analysis of the Met Mast}

The acceleration data between 30 May and 2 June 2016 was analyzed to obtain the natural frequency of the met mast structure. No typhoons or earthquakes occurred in the met mast's vicinity during this period. This study used the characteristics of acceleration in the time domain to interpret the interaction between the met mast and the environmental loads under normal conditions. The short-time Fourier transform (STFT) [26] was used to elucidate the changes in the dynamic characteristics of the met mast over time, and then compared with the results of the finite element models.

Figures 3-6 illustrate the time-series of the acceleration data of the met mast for 30 May, 31 May, 1 June, and 2 June 2016, respectively. The variations of the amplitude over time revealed that the vibration amplitude was the smallest at $10 \mathrm{AM}$ on each day. The largest vibration amplitudes occurred at 2 AM and 3 PM. Taking the 3 PM readings from 30 May 2016 as an example, the magnitude of the accelerations at $74.6 \mathrm{~m}$ (100 gal) were approximately five times that measured at $19 \mathrm{~m}(20 \mathrm{gal})$. Therefore, we can conjecture that the magnitudes of the vibration modes caused by the environmental loads were approximately five times as high near the top of the met mast as they were near the bottom.

We used the STFT to obtain the vibration frequencies of the met mast structure from the X-direction vibration data at a height of $74.6 \mathrm{~m}$ above the MWL on 30 May 2016 (Figure 7). As shown in Figure 7, the characteristic frequencies of the met mast were dominated by the color that represents energy. We can focus on a range of interest $(\sim 5 \mathrm{~Hz})$ and select the characteristic frequencies. Table 3 summarizes these characteristic frequencies and their mode shapes.

Table 3. Characteristic frequencies of met mast structure.

\begin{tabular}{ccc}
\hline Mode Number & Mode Shape & Measured \\
\hline 1 & 1st bending mode (X or Y) & 0.6 \\
2 & 2nd bending mode (X or Y) & 1.4 \\
3 & 3rd bending mode (X or Y) & 2.7 \\
4 & 1st torsional mode & 3.6 \\
5 & 2nd torsional mode & 4.6 \\
\hline
\end{tabular}



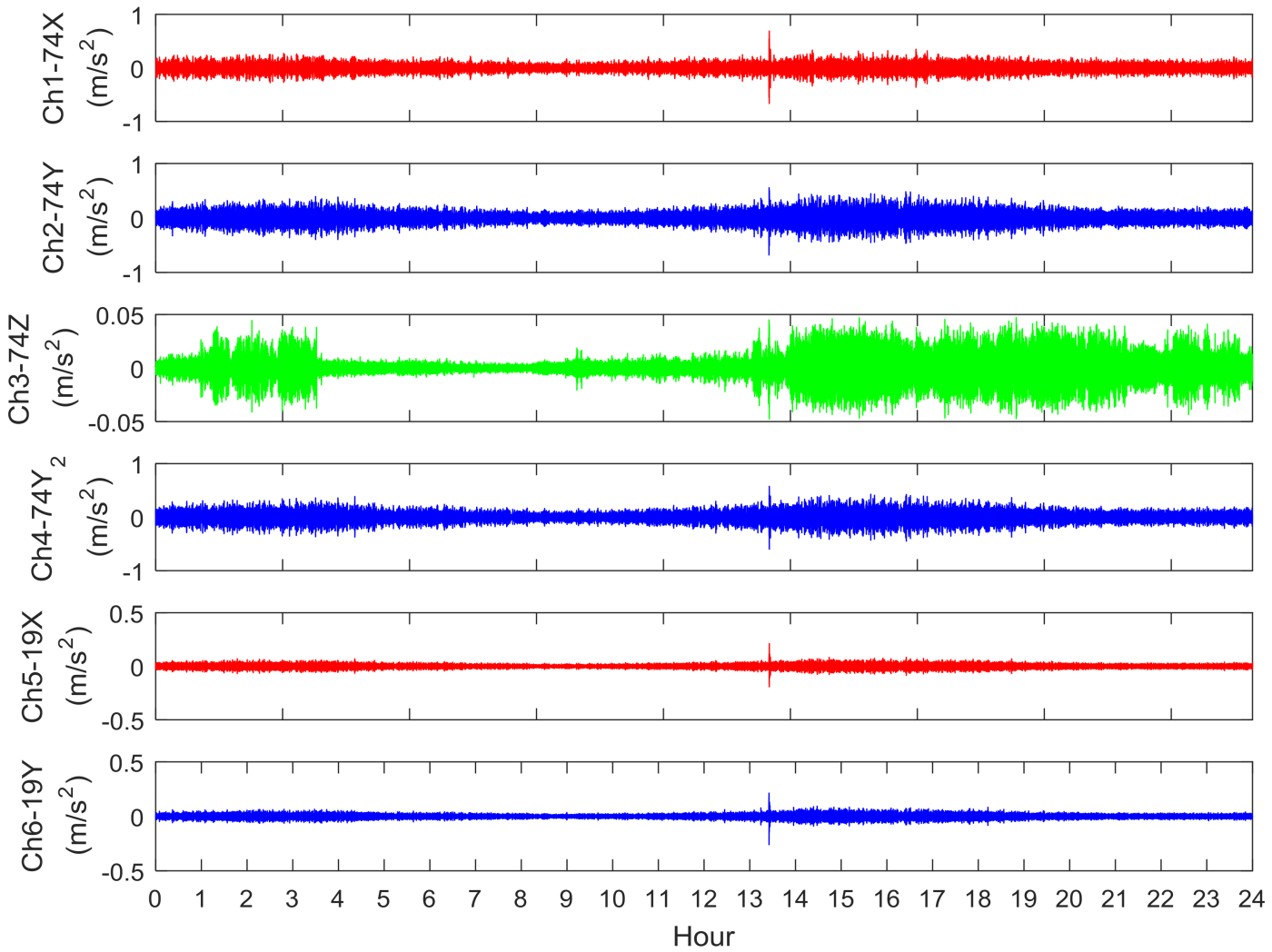

Figure 3. Time-series of acceleration data on 30 May 2016.
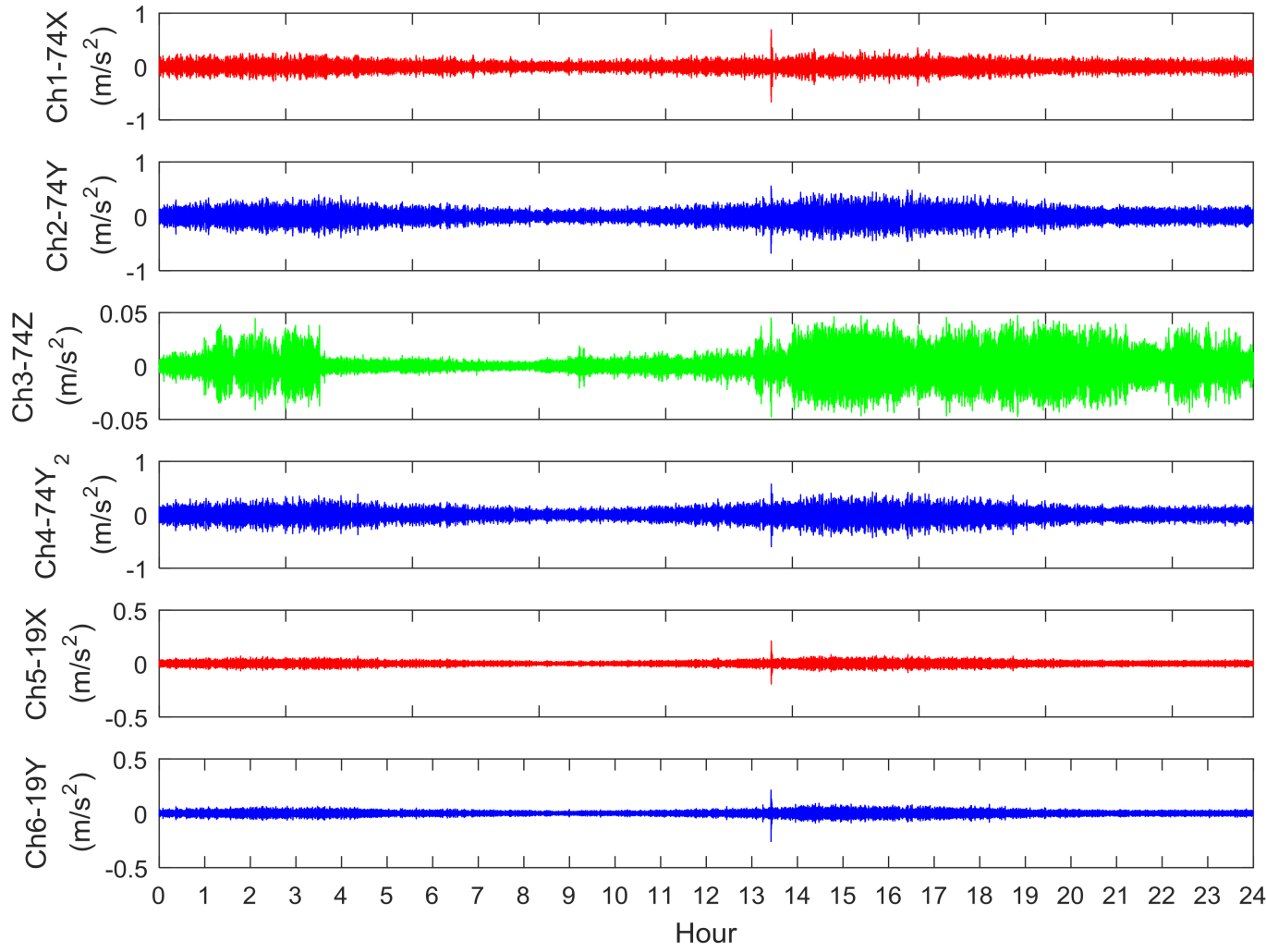

Figure 4. Time-series of acceleration data on 31 May 2016. 

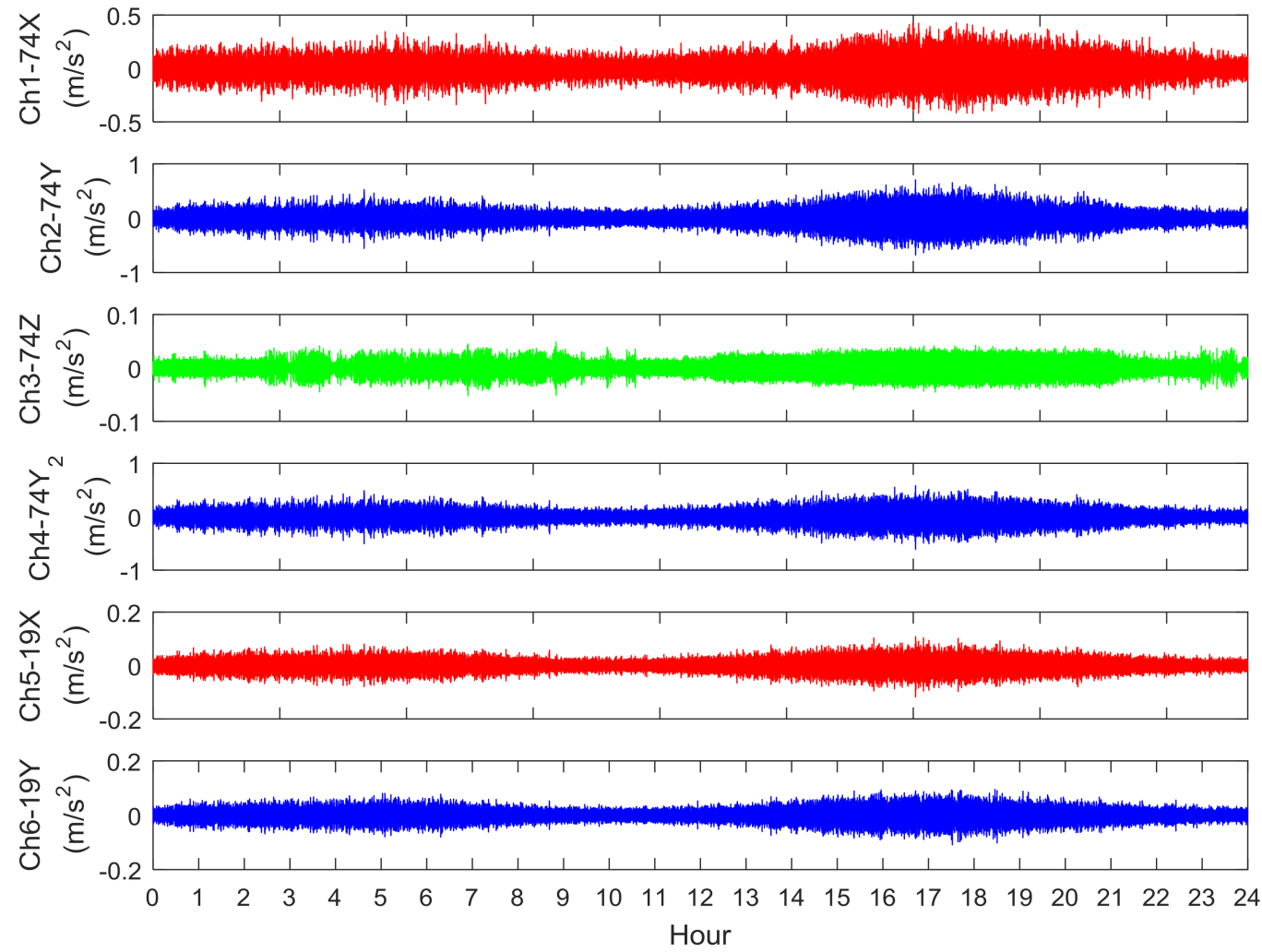

Figure 5. Time-series of acceleration data on 1 June 2016.
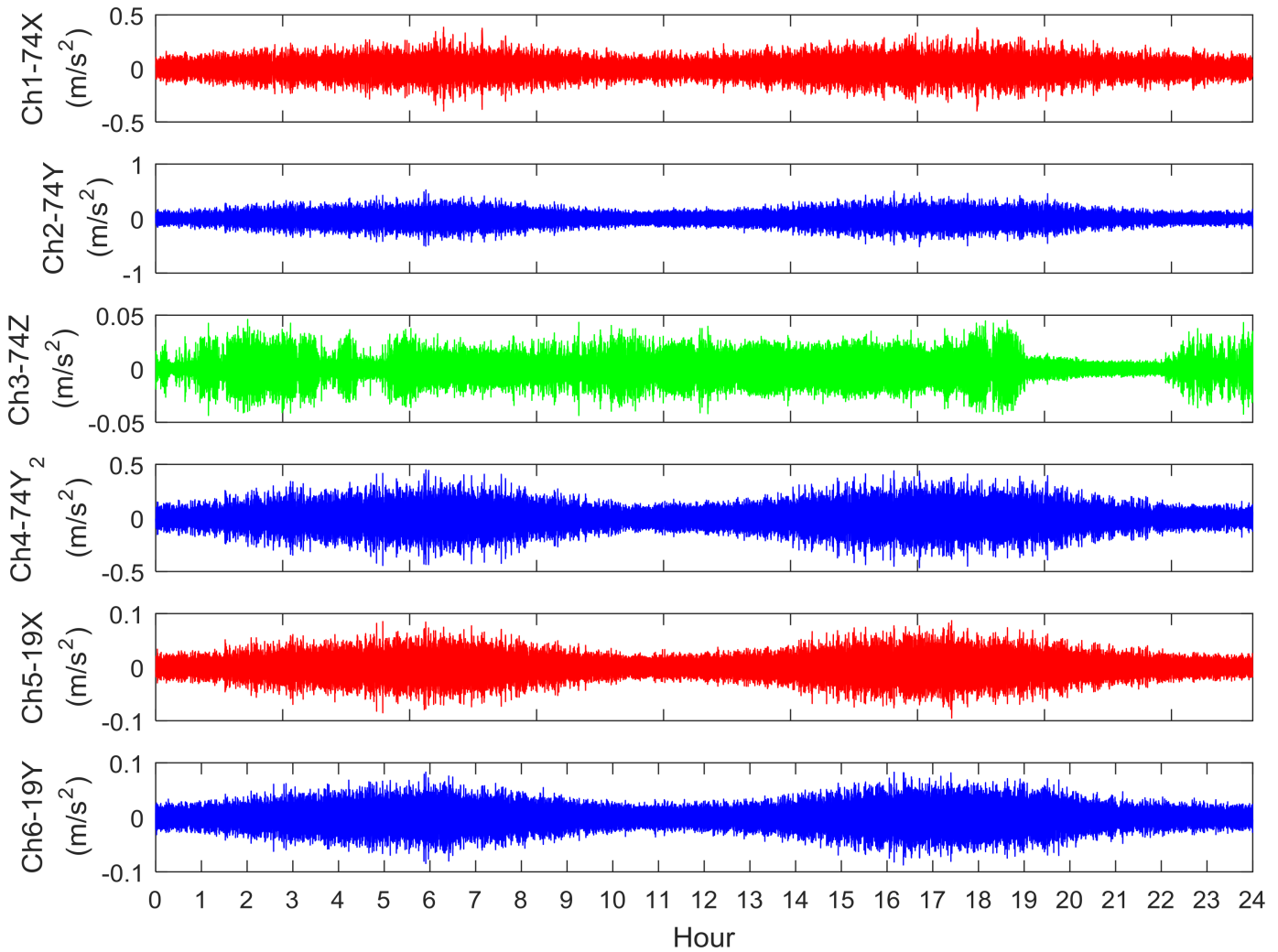

Figure 6. Time-series of acceleration data on 2 June 2016. 


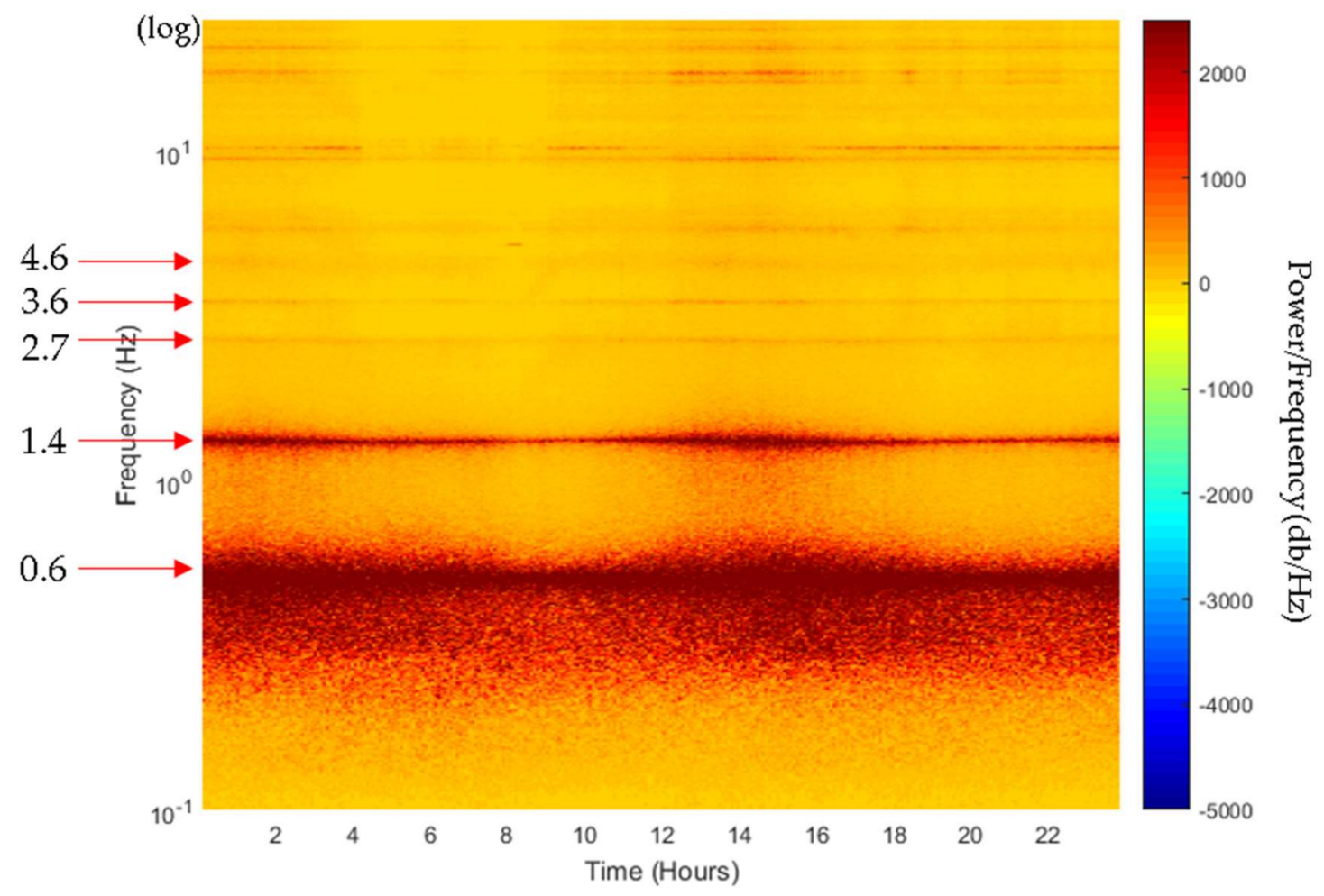

Figure 7. Vibration frequencies of met mast structure on 30 May 2016 (0-25 Hz).

\section{Numerical Model to Analyze the Dynamic Responses of Offshore Structures}

When engineers analyze the vibration responses of offshore structures, the foundation's load-deformation response is generally simplified into the foundation's stiffness matrix in addition to setting up the distributed-springs between the soil and the monopile. The pile-soil interaction springs are combined with the structure to calculate the natural frequencies and the integrated responses (Figure 8) [27-32].

According to Arany et al. [31], the vertical stiffness of a monopile foundation is significantly higher than its stiffness in all other directions. Therefore, the vertical stiffness effects can be omitted to simplify the calculations. The load-displacement response of the monopile foundation can be represented by the lateral spring, rocking spring, and cross-coupled spring. The flexibility matrix of the coupled-springs foundation model was defined as the $2 \times 2$ matrix in Equation (1), where $u$ is the lateral pile head displacement; $\theta=\partial u / \partial z$ is the angle of rotation at the pile head; $H$ is the lateral load applied to the pile head; and $M$ is the bending moment applied to the pile head. When a force $H$ is applied to the foundation (and $M=0$ ), the coefficients $\left(S_{u u}\right.$ and $S_{\theta u}$ ) of the flexibility matrix can be determined using the lateral displacement and the angle of rotation of the pile head at the mudline. When a moment $M$ is applied to the foundation (and $H=0$ ), the coefficients $\left(S_{u \theta}\right.$ and $S_{\theta \theta}$ ) of the flexibility matrix can be calculated using the lateral displacement and the angle of rotation of the pile head. We can invert the flexibility matrix to obtain the stiffness matrix $[K]$ after acquiring it, as shown in Equation (2).

$$
\begin{aligned}
& \left\{\begin{array}{l}
u \\
\theta
\end{array}\right\}=\left[\begin{array}{ll}
S_{u u} & S_{u \theta} \\
S_{\theta u} & S_{\theta \theta}
\end{array}\right]\left\{\begin{array}{c}
H \\
M
\end{array}\right\} \\
& \left\{\begin{array}{c}
H \\
M
\end{array}\right\}=\left[\begin{array}{ll}
K_{u u} & K_{u \theta} \\
K_{\theta u} & K_{\theta \theta}
\end{array}\right]\left\{\begin{array}{l}
u \\
\theta
\end{array}\right\}
\end{aligned}
$$

The stiffness matrix can be used to analyze the dynamic response of the offshore structure under the serviceability limit state. 


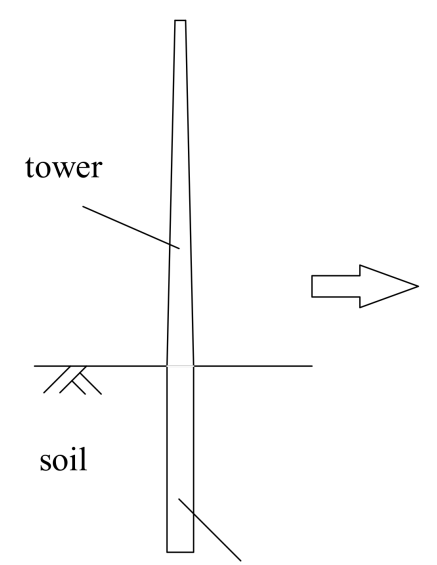

pile

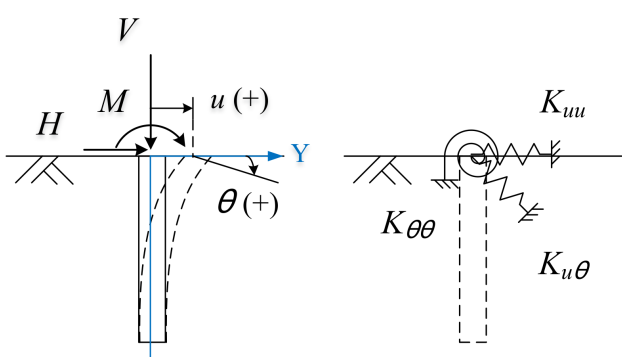

(a)

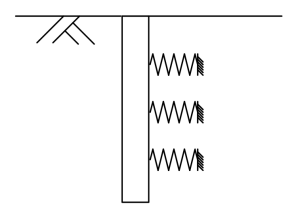

(b)

Figure 8. Simulation types of foundation of offshore structure. (a) Coupled-springs foundation model; (b) Distributed-springs foundation model.

\subsection{Load-Deformation Response of the Pile-Soil Interaction}

The $p-y$ curve method recommended in API [8] and DNV GL [9] is commonly used for analyses when calculating the load-deformation response of a monopile foundation. In the $p-y$ curve method, the pile is considered as an elastic beam supported by a series of nonlinear springs. The soil resistance per length $(p)$ and the lateral deformation $(y)$ response form a $p-y$ curve. Table 2 shows that the monopile foundation of TPC's met mast was embedded in cohesionless seabed soil. Therefore, we used Equation (3), which is the $p-y$ curves recommended by API [8] and DNV GL [9] for piles embedded in cohesionless soil at depth $z$ :

$$
p=A \times p_{u} \times \tanh \left[\frac{n_{h} \times z}{A \times p_{u}} \times y\right],
$$

For piles in offshore environments with cyclic loading, $A=0.9$. The ultimate soil resistance per length $p_{u}$ is the smaller in Equations (4) and (5):

$$
\begin{gathered}
p_{s t}=\gamma / z\left[\frac{K_{0} z \tan \phi \prime \sin \beta}{\tan \left(\beta-\phi^{\prime}\right) \cos \alpha}+\frac{\tan \beta}{\tan \left(\beta-\phi^{\prime}\right)}(D+z \tan \beta \tan \alpha)+K_{0} z \tan \beta\left(\tan \phi^{\prime} \sin \beta-\tan \alpha\right)-K_{a} D\right], \\
p_{s d}=K_{a} D \gamma^{\prime} z\left(\tan ^{8} \beta-1\right)+K_{0} D \gamma^{\prime} z \tan \phi^{\prime} \tan ^{4} \beta
\end{gathered}
$$

The initial stiffness $E_{p y}$ of the $p-y$ curves can be determined by differentiating Equation (3), and is directly proportional to the embedded depth $z$, as shown in Equation (6):

$$
E_{p y}=p \prime(y=0)=n_{h} z
$$

In Equations (4) and (5), $\phi^{\prime}$ is the effective internal friction angle of soil $\left(^{\circ}\right) ; \gamma^{\prime}$ is the effective unit weight of soil $\left(\mathrm{kN} / \mathrm{m}^{3}\right) ; D$ is the pile diameter $(\mathrm{m}) ; \alpha=\phi^{\prime} / 2 ; \beta=45^{\circ}+\phi^{\prime} / 2 ; K_{0}$ is the coefficient of the lateral earth pressure at rest, $K_{0}=1-\sin \phi^{\prime} ; K_{a}$ is the coefficient of the active lateral earth pressure, $K_{a}=\tan ^{2}\left(45^{\circ}-\phi^{\prime} / 2\right)$; and $n_{h}$ is the initial modulus of subgrade reaction $\left(\mathrm{kN} / \mathrm{m}^{3}\right)$ determined by soil conditions, it is not related to the embedded pile depth or pile diameter. Figure 9 shows the relationship among the initial modulus of subgrade reaction, effective friction angle, and relative density as recommended by API [33].

Tseng et al. [34] discussed the effects of the pile diameter and the scour on the $p-y$ curves and compared various corrections to the formula proposed by other researchers. Among them, Kallehave et al. [14] measured the natural frequencies of the support structures of three offshore wind 
turbines to be higher than those obtained using the $p-y$ curve method recommended in API [8]. Consequently, the $p-y$ curve method of calculating the load-deformation response recommended in API [8] underestimated the soil stiffness. According to Reese et al. [35], Lin et al. [23] considered the geometry of the scour hole in the soil wedge and recalculated the ultimate soil resistance per length near the ground surface $p_{s t}$, as shown in Equation (4) based on the force equilibrium. This recalculation resulted in a more reasonable value for the ultimate soil resistance per length near the ground surface. Qi et al. [36] arrived at similar results using pile model tests to simulate the load-deformation of the monopile foundations affected by the local scour. The present study used the method suggested by Kallehave et al. [14] to modify the initial modulus of subgrade reaction $n_{h}$ for the monopile foundations. The method recommended by Lin et al. [23] was used to calculate the ultimate soil resistance per length, substitute both in Equation (3), and re-calculate the $p-y$ curves of the monopile foundations with scouring. Finally, two types of foundation models (Figure 8) were combined with the met mast structure to calculate the natural frequencies and the characteristic shapes of each mode for the met mast structure.

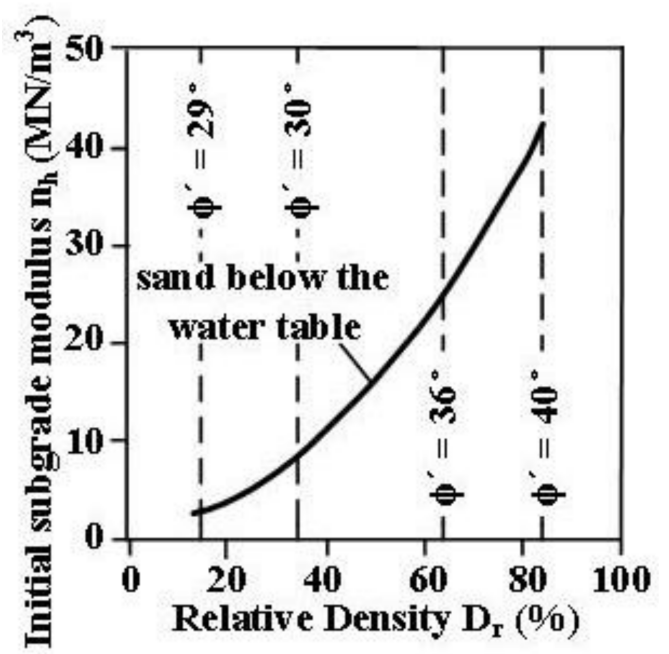

Figure 9. Relationship of the initial modulus of subgrade reaction, the effective friction angle, and relative density.

\subsection{Effect of Scour on the Monopile Foundation Stiffness}

This study used the method recommended by Kallehave et al. [14] to evaluate the effect of scour on the dynamic response of the met mast and correct the initial modulus of subgrade reaction $n_{h}$ of the $p-y$ curves for the monopile foundations. The method proposed by Lin et al. [23] was then used to incorporate the effects of scour into the ultimate soil resistance per length $p_{u}$ and substitute in Equation (3) to obtain the modified $p-y$ curves.

Figure 10 shows the boundary conditions associated with the effects of scour when calculating the foundation stiffness and presents the assumed changes to the seabed elevation with scour depths $S_{d}$ of $0,0.5,1$, and 1.5 times the monopile diameter $D$. Figure 10 a presents the conditions assumed by API [8], which only considered the soil at depths below the bottom of the scour hole when constructing the $p-y$ curves to calculate the load-deformation response of the foundation after the scour has occurred. Figure 10b illustrates the conditions assumed by Lin et al. [23], which considered the geometry of the scour hole when constructing the $p-y$ curves.

Figures 11-13 show the $p-y$ curves for the monopile foundation $(D=3.8 \mathrm{~m})$ embedded in dense sand $\left(\phi^{\prime}=37.5^{\circ}\right)$. The unmodified and modified $p-y$ curves at depths below the bottom of the scour hole $\left(z^{\prime}=0.5 D, 1.5 D\right.$, and $\left.3 D\right)$ were compared for various scour depths $\left(S_{d}=0 D, 0.5 D, 1 D\right.$, and 1.5D). The unmodified $p-y$ curves (dotted line) in the figures were not adjusted for the effects of the pile diameter. The soil above the bottom of the scour hole was removed when the scour occurred. 
The modified $p-y$ curves (solid line) were considered to determine the effects of the pile diameter and the scour hole geometry using the methods suggested by Kallehave et al. [14] and Lin et al. [23]. Figures 11-13 reveal that neither the initial modulus of subgrade reaction nor the ultimate soil resistance per length of the unmodified $p-y$ curves was affected by the scour because the entire layer of soil above the bottom of the scour hole was removed. The initial stiffness of the unmodified $p-y$ curves

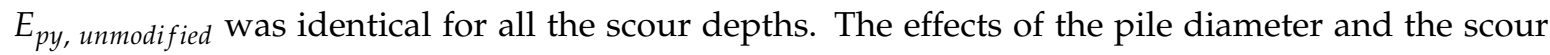
hole geometry were considered for the modified $p-y$ curves. Therefore, the ultimate soil resistance per length $p_{u}$ increased as the scour depth $S_{d}$ increased. However, the initial modulus of subgrade reaction was not affected by the scour depth. The ratio of the initial stiffness $\left(E_{p y, \text { modified }} / E_{p y, \text { unmodified }}\right)$ decreased from 2.8 to 1.4 as the depth below the bottom of the scour hole $z^{\prime}$ increased.

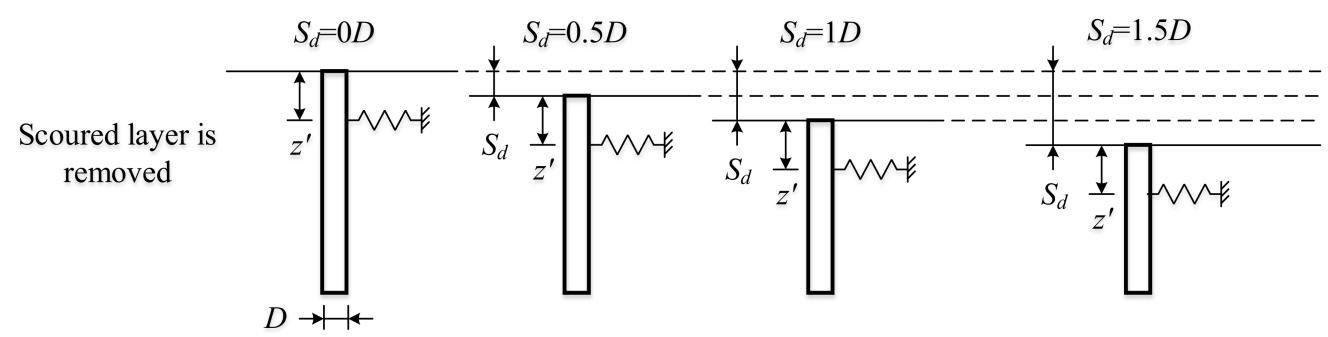

(a)

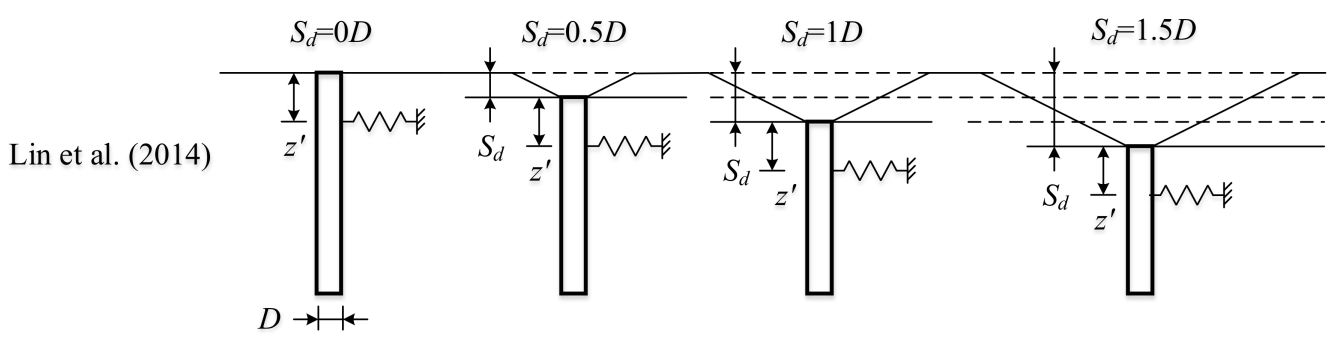

(b)

Figure 10. Boundary conditions of different methods considering the effect of scour. (a) Consider the soil below the bottom of scour hole; (b) Consider the geometry of scour hole.

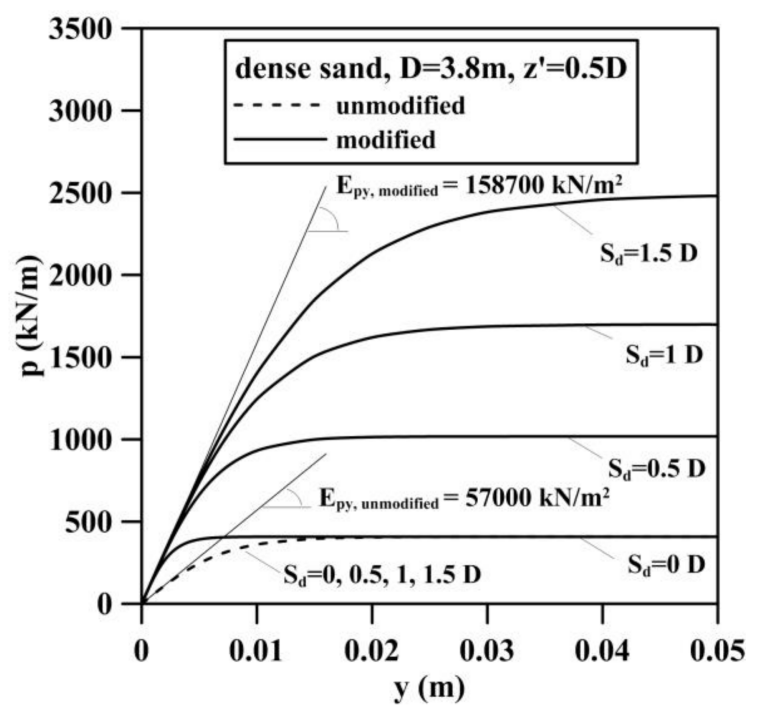

Figure 11. $p-y$ curves for various scour depths at depth of $0.5 D$ below the bottom of the scour hole. $\left(E_{p y, \text { modified }} / E_{p y, \text { unmodified }}=2.8\right)$. 


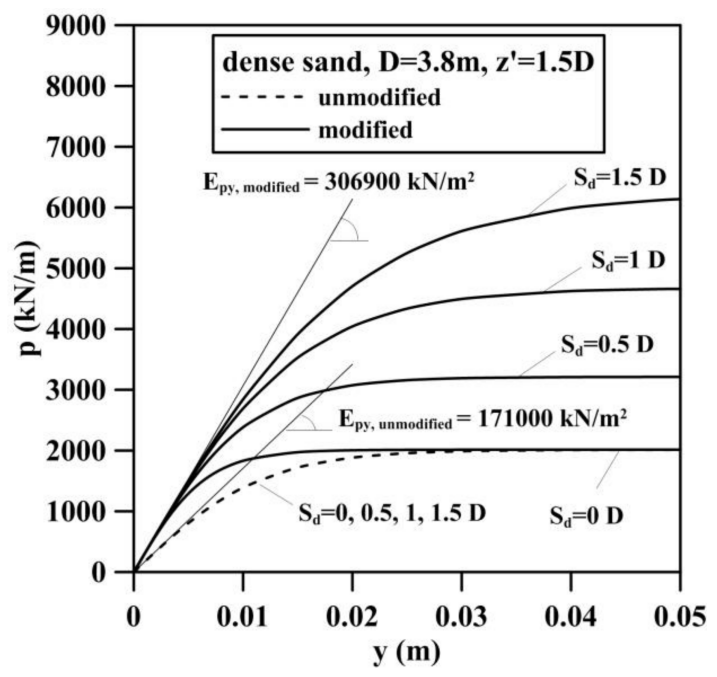

Figure 12. $p-y$ curves for various scour depths at depth of $1.5 D$ below the bottom of the scour hole. $\left(E_{p y, \text { modified }} / E_{p y, \text { unmodified }}=1.8\right)$.

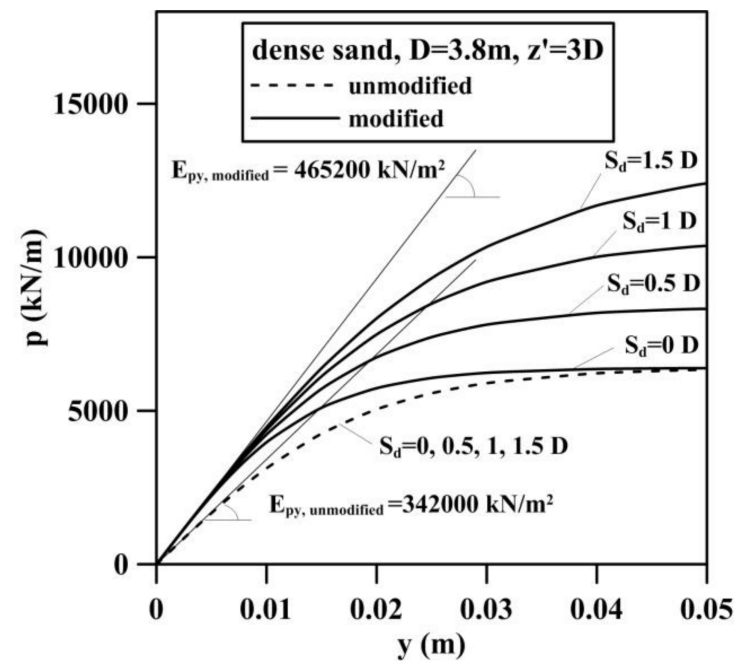

Figure 13. $p-y$ curves for various scour depths at depth of $3 D$ below the bottom of the scour hole. $\left(E_{p y, \text { modified }} / E_{p y, \text { unmodified }}=1.4\right)$.

\section{Effect of Scour on the Vibration Responses of the Met Mast}

The $p-y$ curves for the various scour depths $\left(S_{d}=0 D, 0.5 D, 1 D\right.$, and 1.5D) for the monopile foundation of the met mast (Figure 8) were constructed using both simulation types. The unmodified $p-y$ curves recommended in API [8] ignored the entire soil layer above the bottom of the scour hole (Figure 10a) and the modified $p-y$ curves, which used Kallehave et al.'s [14] modified initial modulus of subgrade reaction and Lin et al.'s [23] modified ultimate lateral soil resistance per length (Figure 10b). Both $p-y$ curves were considered to evaluate the scour effect on the dynamic responses of the met mast. Table 4 presents the conditions of four cases. We used the modified and unmodified $p-y$ curves in cases 1 and 2 to calculate the initial slope of the load-deformation curve of the pile head and determine the foundation stiffness for the met mast structures (Figure 14). Using the concept shown in Figure 8a, we then utilized the commercial software BLADED (4.5, Garrad Hassan \& Partners Ltd., Bristol, UK) [37] to create the coupled-springs foundation model and calculate the dynamic response of the met mast structure (Figure 15a). Table 5 presents the initial foundation stiffness for each scour 
depth. The initial stiffness increased as the scour depth increased; however, the increase was more evident in case 1 than in case 2.

Table 4. Conditions for simulations. API: American Petroleum Institute.

\begin{tabular}{cccc}
\hline Condition & $\begin{array}{c}\text { Type of Simulation for } \\
\text { Monopile Foundation }\end{array}$ & Type of Simulation for Pile-Soil Interaction \\
\hline case 1 & coupled springs & Kallehave et al. [14] + Lin et al. [23] & (Figure 10b) \\
case 2 & coupled springs & API [8] + the entire scoured layer is removed & (Figure 10a) \\
case 3 & distributed springs & Kallehave et al. [14] + Lin et al. [23] & (Figure 10b) \\
case 4 & distributed springs & API [8] + the entire scoured layer is removed & (Figure 10a) \\
\hline
\end{tabular}
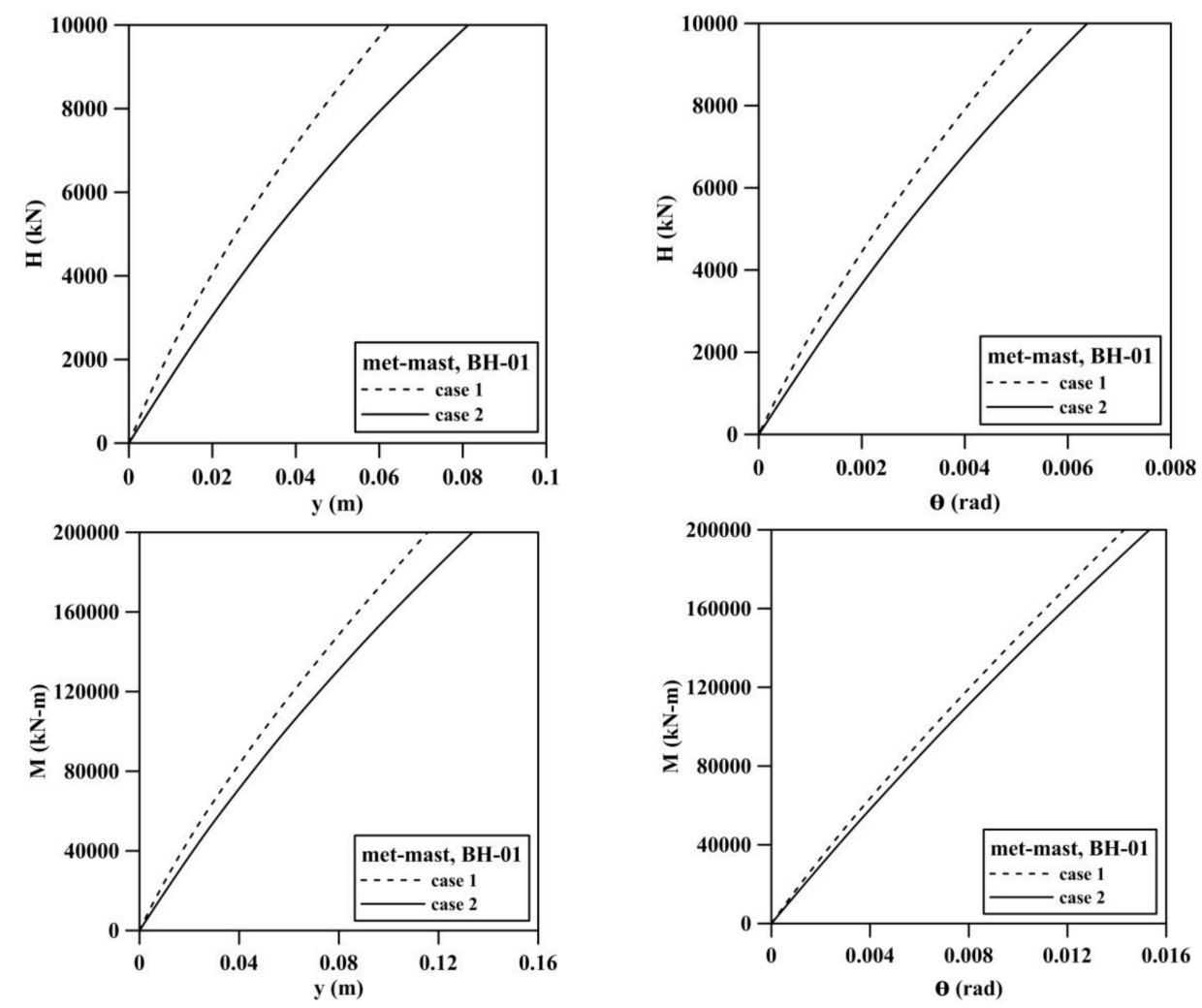

Figure 14. Load-deformation curves of pile head for met mast $\left(S_{d}=0 D\right)$.

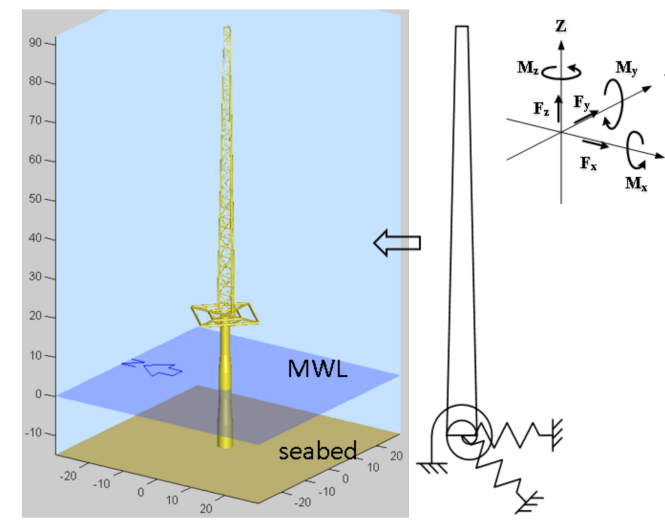

(a)

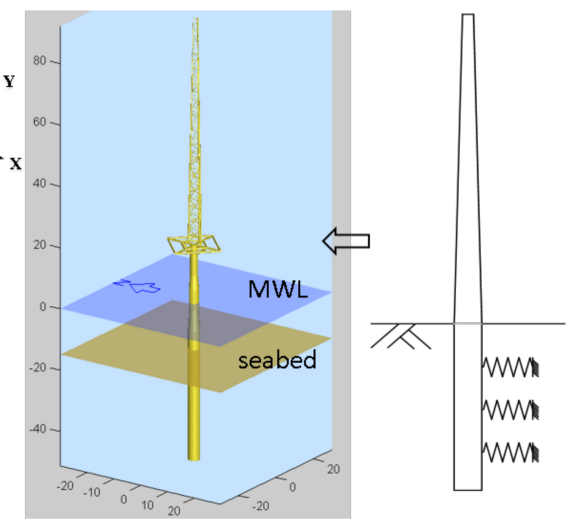

(b)

Figure 15. Numerical model of TPC's met mast. (a) Coupled-springs foundation model; (b) Distributed-springs foundation model. 
Table 5. Initial foundation stiffness of case 1 and case 2 .

\begin{tabular}{|c|c|c|c|c|c|c|}
\hline $\begin{array}{l}\text { Classification of } p-y \text { Curves } \\
\text { Used in This Study }\end{array}$ & & $S_{d} / D$ & 0 & 0.5 & 1 & 1.5 \\
\hline \multirow{4}{*}{ case 1} & $K_{u u}$ & $(\mathrm{kN} / \mathrm{m})$ & $6.29 \times 10^{5}$ & $6.86 \times 10^{5}$ & $7.21 \times 10^{5}$ & $8.08 \times 10^{5}$ \\
\hline & $K_{\theta u}$ & $(\mathrm{kNm} / \mathrm{m})$ & $-4.24 \times 10^{6}$ & $-4.54 \times 10^{6}$ & $-4.71 \times 10^{6}$ & $-5.05 \times 10^{6}$ \\
\hline & $K_{u \theta}$ & $(\mathrm{kN} / \mathrm{rad})$ & $-4.24 \times 10^{6}$ & $-4.54 \times 10^{6}$ & $-4.71 \times 10^{6}$ & $-5.05 \times 10^{6}$ \\
\hline & $K_{\theta \theta}$ & $(\mathrm{kNm} / \mathrm{rad})$ & $4.61 \times 10^{7}$ & $4.77 \times 10^{7}$ & $4.84 \times 10^{7}$ & $4.98 \times 10^{7}$ \\
\hline \multirow{4}{*}{ case 2} & $K_{u u}$ & $(\mathrm{kN} / \mathrm{m})$ & $4.43 \times 10^{5}$ & $4.70 \times 10^{5}$ & $5.00 \times 10^{5}$ & $5.36 \times 10^{5}$ \\
\hline & $K_{\theta u}$ & $(\mathrm{kNm} / \mathrm{m})$ & $-3.46 \times 10^{6}$ & $-3.61 \times 10^{6}$ & $-3.76 \times 10^{6}$ & $-3.92 \times 10^{6}$ \\
\hline & $K_{u \theta}$ & $(\mathrm{kN} / \mathrm{rad})$ & $-3.46 \times 10^{6}$ & $-3.61 \times 10^{6}$ & $-3.76 \times 10^{6}$ & $-3.92 \times 10^{6}$ \\
\hline & $K_{\theta \theta}$ & $(\mathrm{kNm} / \mathrm{rad})$ & $4.20 \times 10^{7}$ & $4.28 \times 10^{7}$ & $4.36 \times 10^{7}$ & $4.43 \times 10^{7}$ \\
\hline
\end{tabular}

Cases 3 and 4 convert the $p-y$ curves into load-deformation curves for each node of the monopile according to the concept in Figure $8 \mathrm{~b}$. BLADED was used to construct the distributed-springs foundation model to analyze the dynamic response of the met mast (Figure 15b). The foundation stiffness matrix is shown in Equation (7) according to the transform of the coordinate system. The density of steel in the coupled-springs and distributed springs models was $7850 \mathrm{~kg} / \mathrm{m}^{3}$. The bending stiffness and the weight of tower per meter from the top to the bottom are $8.37 \times 10^{5}-4.57 \times 10^{7} \mathrm{kNm}^{2}$ and $154-1420 \mathrm{~kg} / \mathrm{m}$. The elastic modulus of steel was $2.1 \times 10^{8} \mathrm{kN} / \mathrm{m}^{2}$. The effects of the foundation scour on the natural frequencies of the met mast structure obtained from the modal analysis were discussed:

$$
\left\{\begin{array}{c}
F_{x} \\
F_{y} \\
M_{x} \\
M_{y}
\end{array}\right\}=\left[\begin{array}{cccc}
K_{u u} & 0 & 0 & -K_{u \theta} \\
0 & K_{u u} & K_{u \theta} & 0 \\
0 & K_{\theta u} & K_{\theta \theta} & 0 \\
-K_{\theta u} & 0 & 0 & K_{\theta \theta}
\end{array}\right]\left\{\begin{array}{l}
u_{x} \\
u_{y} \\
\theta_{x} \\
\theta_{y}
\end{array}\right\}
$$

\subsection{Verification of the Numerical Model}

Tables 6-9 present the natural frequencies of the met mast structure calculated using the numerical models in Figure 15a,b. For the no scour condition $\left(S_{d}=0 D\right)$, the natural frequencies obtained using the foundation simulation in Figure $8 \mathrm{a}$ (Tables 6 and 7) and the results obtained using the foundation simulation in Figure $8 \mathrm{~b}$ (Tables 8 and 9) significantly differed. The natural frequencies obtained using the distributed-springs foundation model (Figure $8 b$ ) more closely matched the measured data (see Tables 8 and 9). This finding showed that the selection of the simulation model type was critical in the modal analysis. The coupled-springs foundation model (Figure 8a) was likely to underestimate the foundation stiffness, causing the natural frequencies of the met mast structure to deviate from the measured values. The distributed-springs foundation model (Figure $8 b$ ) can more reasonably simulate the actual vibration response of the met mast. Tables 6 and 7 reveal that the coupled-springs foundation model (Figure 8a) can result in the natural frequencies of the met mast structure to differ from the measured values by up to $4.7 \%$, showing that correcting the initial stiffness of the $p-y$ curves affects the natural frequencies of the met mast structure. Therefore, if the coupled-springs foundation model is used to simulate the dynamic behavior of the offshore structure, the calculation of the monopile foundation stiffness should consider the effect of the pile diameter under a small strain. Tables 8 and 9 reveal that when $S_{d}=0 D$, the natural frequencies of the met mast structure calculated using the distributed-springs foundation model (Figure $8 \mathbf{b}$ ) were not sensitive to a correction in the initial stiffness of the $p-y$ curves (cases 3 and 4 , Table 4). Therefore, if the distributed-springs foundation model is used, the natural frequencies of the offshore structure do not depend on the corrections in the initial stiffness of the $p-y$ curves. 
Table 6. Natural frequencies of met mast structure—case 1.

\begin{tabular}{cccccc}
\hline \multirow{2}{*}{ Mode Shape } & Measured (Table 3) & \multicolumn{4}{c}{ Simulated } \\
\cline { 3 - 6 } & & $S_{\boldsymbol{d}}=\mathbf{0 D}$ & $\boldsymbol{S}_{\boldsymbol{d}}=\mathbf{0 . 5 D}$ & $\boldsymbol{S}_{\boldsymbol{d}}=\mathbf{1 D}$ & $\boldsymbol{S}_{\boldsymbol{d}}=\mathbf{1 . 5 D}$ \\
\hline \multirow{2}{*}{ 1st bending mode (X or Y) } & \multirow{2}{*}{0.6} & 0.575 & 0.568 & 0.561 & 0.555 \\
& & 0.588 & 0.580 & 0.572 & 0.566 \\
\hline \multirow{2}{*}{ 2nd bending mode (X or Y) } & \multirow{2}{*}{1.4} & 1.035 & 1.005 & 0.975 & 0.950 \\
& & 1.037 & 1.007 & 0.977 & 0.952 \\
\hline \multirow{2}{*}{ 3rd bending mode (X or Y) } & \multirow{2}{*}{2.7} & 2.196 & 2.140 & 2.088 & 2.049 \\
\hline 1st torsional mode & 3.6 & 2.207 & 2.151 & 2.099 & 2.059 \\
\hline 2nd torsional mode & 4.6 & 2.911 & 2.902 & 2.892 & 2.883 \\
\hline
\end{tabular}

Table 7. Natural frequencies of met mast structure-case 2.

\begin{tabular}{cccccc}
\hline \multirow{2}{*}{ Mode Shape } & Measured (Table 3) & \multicolumn{4}{c}{ Simulated } \\
\cline { 3 - 6 } & & $S_{d}=\mathbf{0 D}$ & $S_{d}=\mathbf{0 . 5 D}$ & $S_{d}=\mathbf{1 D}$ & $S_{d}=\mathbf{1 . 5 D}$ \\
\hline \multirow{2}{*}{ 1st bending mode (X or Y) } & \multirow{2}{*}{0.6} & 0.566 & 0.559 & 0.552 & 0.545 \\
& & 0.578 & 0.570 & 0.563 & 0.556 \\
\hline \multirow{2}{*}{ 2nd bending mode (X or Y) } & \multirow{2}{*}{1.4} & 0.996 & 0.967 & 0.939 & 0.914 \\
& & 0.998 & 0.969 & 0.941 & 0.915 \\
\hline \multirow{2}{*}{ 3rd bending mode (X or Y) } & \multirow{2}{*}{2.7} & 2.126 & 2.077 & 2.034 & 1.996 \\
\hline 1st torsional mode & \multirow{2}{*}{3.6} & 2.137 & 2.088 & 2.044 & 2.006 \\
\hline 2nd torsional mode & 4.6 & 2.910 & 2.901 & 2.891 & 2.882 \\
\hline
\end{tabular}

Table 8. Natural frequencies of met mast structure-case 3.

\begin{tabular}{cccccc}
\hline \multirow{2}{*}{ Mode Shape } & Measured (Table 3) & \multicolumn{4}{c}{ Simulated } \\
\cline { 3 - 6 } & & $S_{d}=\mathbf{0 D}$ & $S_{d}=\mathbf{0 . 5 D}$ & $S_{d}=\mathbf{1 D}$ & $S_{d}=\mathbf{1 . 5 D}$ \\
\hline \multirow{2}{*}{ 1st bending mode (X or Y) } & \multirow{2}{*}{0.6} & 0.623 & 0.617 & 0.611 & 0.604 \\
& & 0.640 & 0.633 & 0.626 & 0.619 \\
\hline \multirow{2}{*}{ 2nd bending mode (X or Y) } & \multirow{2}{*}{1.4} & 1.234 & 1.210 & 1.184 & 1.157 \\
& & 1.237 & 1.213 & 1.187 & 1.160 \\
\hline \multirow{2}{*}{ 3rd bending mode (X or Y) } & \multirow{2}{*}{2.7} & 2.755 & 2.670 & 2.580 & 2.493 \\
\hline 1st torsional mode & \multirow{2}{*}{3.6} & 2.785 & 2.688 & 2.595 & 2.506 \\
\hline 2nd torsional mode & 4.6 & 2.947 & 2.922 & 2.905 & 2.892 \\
\hline
\end{tabular}

Table 9. Natural frequencies of met mast structure—case 4 .

\begin{tabular}{cccccc}
\hline \multirow{2}{*}{ Mode Shape } & Measured (Table 3) & \multicolumn{4}{c}{ Simulated } \\
\cline { 3 - 6 } & & $S_{d}=\mathbf{0 D}$ & $S_{d}=\mathbf{0 . 5 D}$ & $S_{d}=\mathbf{1 D}$ & $S_{d}=\mathbf{1 . 5 D}$ \\
\hline \multirow{2}{*}{ 1st bending mode (X or Y) } & \multirow{2}{*}{0.6} & 0.623 & 0.617 & 0.611 & 0.604 \\
& & 0.640 & 0.633 & 0.626 & 0.619 \\
\hline \multirow{2}{*}{ 2nd bending mode (X or Y) } & \multirow{2}{*}{1.4} & 1.234 & 1.210 & 1.184 & 1.157 \\
& & 1.237 & 1.212 & 1.187 & 1.159 \\
\hline \multirow{2}{*}{ 3rd bending mode (X or Y) } & \multirow{2}{*}{2.7} & 2.754 & 2.668 & 2.579 & 2.492 \\
\hline 1st torsional mode & \multirow{2}{*}{3.6} & 2.783 & 2.686 & 2.593 & 2.505 \\
\hline 2nd torsional mode & 4.6 & 2.946 & 2.922 & 2.905 & 2.892 \\
\hline
\end{tabular}

\subsection{Effect of Seabed Elevation Caused by Scour on the Natural Frequency}

According to the abovementioned analyses, the distributed-springs foundation model (Figure $8 \mathrm{~b}$ ) when the seabed scour depth is $S_{d}=0 D$ can more reasonably calculate the natural frequencies of 
the met mast structure (cases 3 and 4, Table 4). Therefore, the analysis that follows focuses on the results in Tables 8 and 9 to discuss the effect of scour on the natural frequencies of the met mast structure. The degree of degradation for different modes was not identical in terms of the natural frequencies of the met mast structure that varied with the scour depth. Table 10 summarizes the modal frequencies for which the effect of scour was significant. The mode shapes of modes 4, 5, 7, 8 , and 24 were horizontal bending modes, whereas those of modes 22 and 36 were vertical bending modes. Figures 16 and 17 show the natural frequency ratios $\left(f_{n} / f_{n, S_{d}=0 D}\right)$ of the various modes at different scour depths $\left(S_{d}=0 D, 0.5 D, 1 D\right.$, and $\left.1.5 D\right)$, where $f_{n}$ is the natural frequency of the met mast structure with scour, and $f_{n, S_{d}=0 D}$ is the natural frequency of the met mast structure without scour. All the natural frequency ratios decreased as the scour depth increased. The natural frequency of modes $4,5,7,8,22,24$, and 36 decreased by $6-14 \%$ when the scour depth was 1.5 times the pile diameter $\left(S_{d}=1.5 D\right)$ (Figures 13 and 14). In other words, the foundation scour exerted a critical influence on the modal analysis. The natural frequencies of the met mast structure in Table 8 (case 3, Table 4) and 9 (case 4 , Table 4 ) differed by a maximum of $1 \%$. Therefore, if the distributed-springs model is used to simulate the dynamic response of the met mast, the natural frequency of the met mast structure is not sensitive to use the unmodified $p-y$ curves recommended in API [8] or the modified $p-y$ curves combined Kallehave et al.'s [14] method and Lin et al.'s [23] method.

Table 10. Natural frequencies of vibration modes in case 3 and case 4 .

\begin{tabular}{|c|c|c|c|c|c|c|c|c|c|}
\hline $\begin{array}{c}\text { Mode } \\
\text { Number }\end{array}$ & Mode Shape & \multicolumn{4}{|c|}{ Case 3} & \multicolumn{4}{|c|}{ Case 4} \\
\hline 4 & fore-aft 1st bending mode & 1.234 & 1.21 & 1.184 & 1.157 & 1.234 & 1.21 & 1.184 & 1.157 \\
\hline 7 & fore-aft 2 nd bending mode & 2.755 & 2.67 & 2.58 & 2.493 & 2.754 & 2.668 & 2.579 & 2.492 \\
\hline 8 & side-side 2 nd bending mode & 2.785 & 2.688 & 2.595 & 2.506 & 2.783 & 2.686 & 2.593 & 2.505 \\
\hline 22 & 1st vertical mode & 12.368 & 11.87 & 11.329 & 10.872 & 12.272 & 11.77 & 11.24 & 10.803 \\
\hline
\end{tabular}

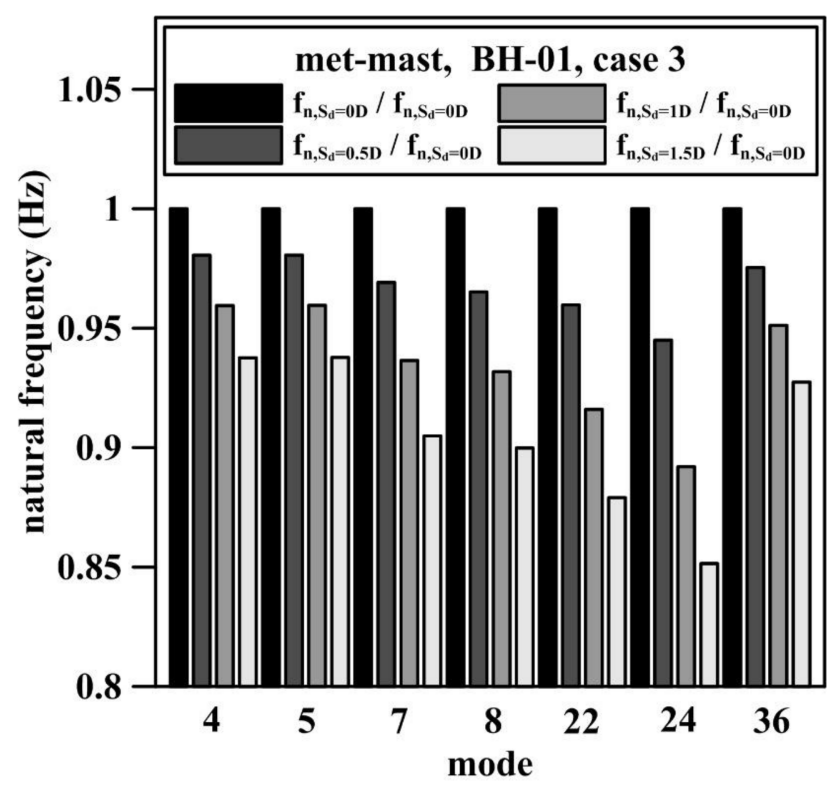

Figure 16. Natural frequency ratios of vibration modes-case 3.

According to Lin et al. [23], scour mainly reduces the ultimate lateral soil resistance per length of the $p-y$ curve. However, when calculating the natural frequencies of the met mast structure, we mainly considered the soil behavior surrounding the monopile under a small strain. Therefore, the changes in the ultimate lateral soil resistance per length will not significantly influence the dynamic response of 
the met mast. Whether we remove the entire soil layer (case 4, Table 4) or use the method recommended by Lin et al. [23] to incorporate scour into the $p-y$ curve correction (case 3, Table 4), the vibration response of the met mast will not be affected.

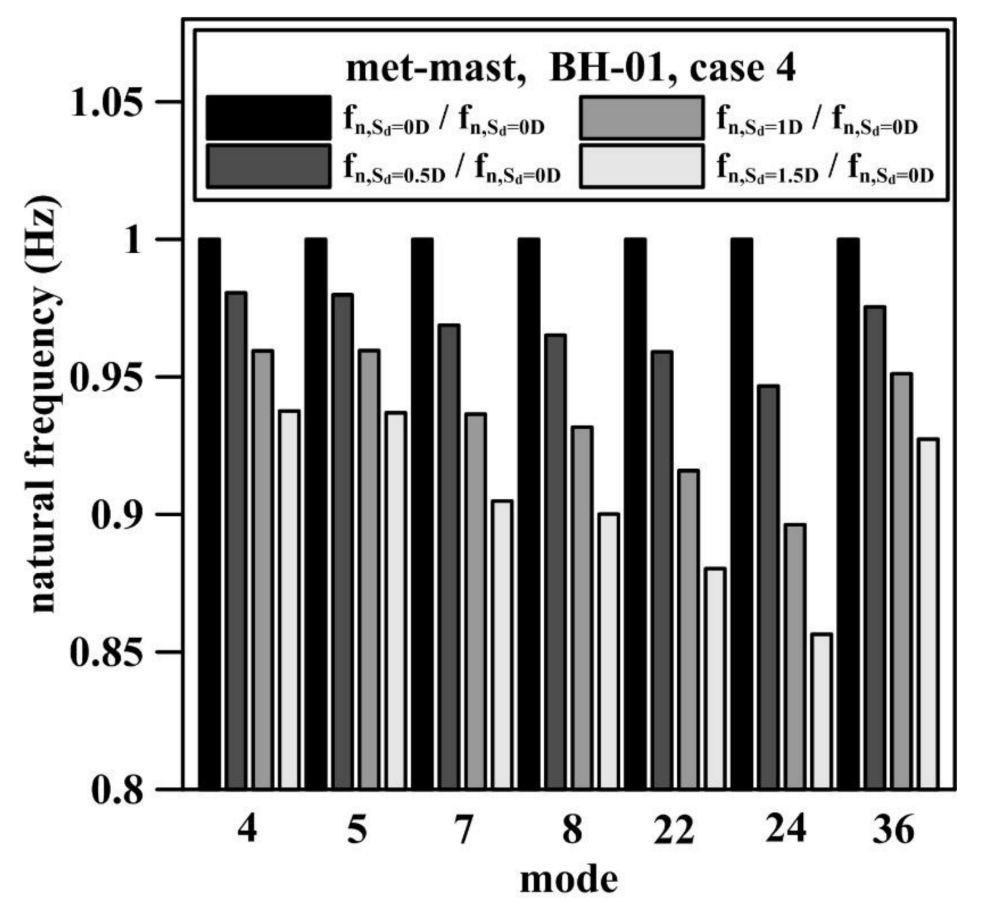

Figure 17. Natural frequency ratios of vibration modes-case 4.

\section{Conclusions}

This study combined Kallehave et al.'s [14] method of correcting the initial stiffness of the $p-y$ curves based on the measured data of the offshore wind turbine in operation and Lin et al.'s [23] method of recalculating the ultimate soil resistance per length considering the scour hole geometry to propose a foundation design procedure that can take both pile diameter and scour effects into consideration. The method was verified using the vibration data collected from TPC's meteorological mast. A comprehensive parameter study with a numerical model showed the scour effect on the natural frequencies of the met mast structure. If a coupled-springs foundation model is used to simulate the monopile foundation in the dynamic response analysis of the met mast, the changes in the initial stiffness of the $p-y$ curves caused by scour exert a significant effect on the natural frequency of the met mast structure. Meanwhile, when a distributed-springs foundation model is used in the dynamic response analysis of the met mast, the natural frequency of the met mast structure calculated by the numerical model is not sensitive to the changes in the initial stiffness of the $p-y$ curves. The results demonstrated that using a distributed-springs foundation model provides a relatively accurate estimate of the natural frequencies of the met mast structure. Furthermore, the scour exerted significant effects on certain modes of the vibration responses. The natural frequencies of the met mast structure can reduce by approximately $14 \%$ due to scour, particularly in the horizontal bending modes. For the vibration analysis of offshore wind turbine support structure, the effect of scour should be considered and the distributed-springs model is recommended to calculate the dynamic response of support structures with monopile foundations. This paper shows the feasibility of using structure monitoring and analysis methods to detect the scour around the monopile foundations of offshore wind turbines. 
Acknowledgments: The research was supported by the grants "Development of monitoring database and application module for meteorology mast (Project No. TPC-546-4320-0301)", the Taiwan Power Company; and "Parameters Study and Application of Stiffness Degradation Mothed (MOST 106-2221-E-006-110-)", the Ministry of Science and Technology of Taiwan.

Author Contributions: Yu-Shu Kuo conceived the study. Yu-Shu Kuo, Wei-Chen Tseng and Kung-Chun Lu collected the vibration data. Wei-Chen Tseng carried out the $p-y$ curves analysis and case study. Kung-Chun Lu carried out the vibration analysis. Yu-Shu Kuo, Wei-Chen Tseng and Kung-Chun Lu analyzed the data. Jing-Wen Chen, Chiou-Fong Chung and Ruey-Chyi Chen give some suggestion for the manuscript editing. Yu-Shu Kuo supervised the study and edited the manuscript. Yu-Shu Kuo is the Principal investigator of project "Development of monitoring database and application module for meteorology mast (Project No. TPC-546-4320-0301)" and "Parameters Study and Application of Stiffness Degradation Mothed (MOST 106-2221-E-006-110-)".

Conflicts of Interest: The authors declare no conflict of interest.

\section{References}

1. DNV/Risø. Guidelines for Design of Wind Turbines, 2nd ed.; Jydsk Centraltrykkeri: Viby, Denmark, 2002.

2. Nikitas, G.; Vimalan, N.J.; Bhattacharya, S. An innovative cyclic loading device to study long term performance of offshore wind turbines. Soil Dyn. Earthq. Eng. 2016, 82, 154-160. [CrossRef]

3. Damgaard, M.; Zania, V.; Andersen, L.V.; Ibsen, L.B. Effects of soil-structure interaction on real time dynamic response of offshore wind turbines on monopiles. Eng. Struct. 2014, 75, 388-401. [CrossRef]

4. Bhattacharya, S.; Nikitas, N.; Garnsey, J.; Alexander, N.A.; Cox, J.; Lombardi, D.; Wood, D.M.; Nash, D.F. Observed dynamic soil-structure interaction in scale testing of offshore wind turbine foundations. Soil Dyn. Earthq. Eng. 2013, 54, 47-60. [CrossRef]

5. Arany, L.; Bhattacharya, S.; Macdonald, J.; Hogan, S.J. Design of monopiles for offshore wind turbines in 10 steps. Soil Dyn. Earthq. Eng. 2017, 92, 126-152. [CrossRef]

6. Versteijlen, W.G.; Metrikine, A.V.; van Dalen, K.N. A method for identification of an effective Winkler foundation for large-diameter offshore wind turbine support structures based on in-situ measured small-strain soil response and 3D modelling. Eng. Struct. 2016, 124, 221-236. [CrossRef]

7. Prendergast, L.J.; Gavin, K. A comparison of initial stiffness formulations for small-strain soil-pile dynamic Winkler modelling. Soil Dyn. Earthq. Eng. 2016, 81, 27-41. [CrossRef]

8. API RP 2GEO. Geotechnical and Foundation Design Considerations; American Petroleum Institute: Washington, DC, USA, 2011.

9. DNV GL AS. Support Structures for Wind Turbines; Standard DNV GL-ST-0126; DNV GL AS: Oslo, Norway, 2016.

10. Abdel-Rahman, K.; Achmus, M. Finite element modelling of horizontally loaded monopile foundations for offshore wind energy converters in Germany. In Proceedings of the First International Symposium on Frontiers in Offshore Geotechnics, Perth, Australia, 19-21 September 2005; Taylor and Francis: Boca Raton, FL, USA, August 2005; pp. 391-396.

11. Lesny, K.; Wiemann, J. Finite-Element-Modelling of Large Diameter Monopiles for Offshore Wind Energy Converters. In Proceedings of the GeoCongress 2006, Atlanta, GA, USA, 26 February-1 March 2006. [CrossRef]

12. Sørensen, S.P.H.; Ibsen, L.B.; Augustesen, A.H. Effects of diameter on initial stiffness of py curves for large-diameter piles in sand. In Proceedings of the European Conference on Numerical Methods in Geotechnical Engineering, Trondheim, Norway, 2-4 June 2010.

13. Sørensen, S.P.H. Soil-Structure Interaction for Non-Slender, Large-Diameter Offshore Monopiles. Ph.D. Thesis, Aalborg University, Aalborg, Denmark, 2012.

14. Kallehave, D.; Thilsted, C.L.; Liingaard, M.A. Modification of the API py Formulation of Initial Stiffness of Sand, Offshore Site Investigation and Geotechnics: Integrated Technologies-Present and Future; Society of Underwater Technology: London, UK, 2012.

15. Sumer, B.M.; Fredsøe, J. The Mechanics of Scour in the Marine Environment; World Scientific: Singapore, 2002.

16. Whitehouse, R.; Sutherland, J.; O'Brien, D. Seabed scour assessment for offshore windfarm. In Proceedings of the 3rd International Conference on Scour and Erosion, Gouda, The Netherlands, 3-5 July 2006.

17. Li, Y.; Chen, X.; Fan, S.; Briaud, J.L.; Chen, H.C. Is scour important for pile foundation design in deepwater? In Proceedings of the Offshore Technology Conference, Houston, TX, USA, 4-7 May 2009. 
18. Achmus, M.; Kuo, Y.S.; Abdel-Rahman, K. Numerical investigation of scour effect on lateral resistance of windfarm monopiles. In Proceedings of the Twentieth International Offshore and Polar Engineering Conference, Beijing, China, 20-25 June 2010.

19. Qi, W.G.; Gao, F.P. Physical modeling of local scour development around a large-diameter monopile in combined waves and current. Coastal Eng. 2014, 83, 72-81. [CrossRef]

20. Det Norske Veritas AS. Design of Offshore Wind Turbine Structures; DNV-OS-J101; Det Norske Veritas AS: Oslo, Norway, 2004.

21. Zaaijer, M.B. Design Methods for Offshore Wind Turbines at Exposed Sites (OWTES)—Sensitivity Analysis for Foundations of Offshore Wind Turbines; Delft University of Technology: Delft, The Netherlands, 2002.

22. Lin, C.; Bennett, C.; Han, J.; Parsons, R.L. Scour effects on the response of laterally loaded piles considering stress history of sand. Comput. Geotech. 2010, 37, 1008-1014. [CrossRef]

23. Lin, C.; Han, J.; Bennett, C.; Parsons, R.L. Analysis of laterally loaded piles in sand considering scour hole dimensions. J. Geotech. Geoenviron. Eng. 2014, 140. [CrossRef]

24. Taiwan Power Company. Development of Monitoring Database and Application Module for Meteorology Mast; Taiwan Power Company: Taipei, Taiwan, 2017.

25. Wang, Y.K.; Chai, J.F.; Chang, Y.W.; Huang, T.Y.; Kuo, Y.S. Development of seismic demand for Chang-Bin offshore wind farm in Taiwan Strait. Energies 2016, 9, 1036. [CrossRef]

26. Cohen, L. Time-Frequency Analysis; Prentice Hall: Upper Saddle River, NJ, USA, 1995.

27. Zaaijer, M.B. Foundation modelling to assess dynamic behaviour of offshore wind turbines. Appl. Ocean Res. 2006, 28, 45-57. [CrossRef]

28. Jonkman, J.; Musial, W. Offshore Code Comparison Collaboration (OC3) for IEA Wind Task 23 Offshore Wind Technology and Deployment; National Renewable Energy Laboratory: Golden, CO, USA, 2010.

29. Bush, E.; Manuel, L. The influence of foundation modeling assumptions on long-term load prediction for offshore wind turbines. In Proceedings of the ASME 28th International Conference on Ocean, Offshore and Arctic Engineering, Honolulu, HI, USA, 31 May-5 June 2009.

30. Lombardi, D.; Bhattacharya, S.; Wood, D.M. Dynamic soil-structure interaction of monopile supported wind turbines in cohesive soil. Soil Dyn. Earthq. Eng. 2013, 49, 165-180. [CrossRef]

31. Arany, L.; Bhattacharya, S.; Adhikari, S.; Hogan, S.J.; Macdonald, J.H.G. An analytical model to predict the natural frequency of offshore wind turbines on three-spring flexible foundations using two different beam models. Soil Dyn. Earthq. Eng. 2015, 74, 40-45.

32. Jung, S.; Kim, S.R.; Patil, A.; Hung, L.C. Effect of monopile foundation modeling on the structural response of a 5-MW offshore wind turbine tower. Ocean Eng. 2015, 109, 479-488. [CrossRef]

33. API RP2A-WSD. Recommended Practice for Planning, Designing and Constructing Fixed Offshore Platforms-Working Stress Design; American Petroleum Institute: Washington, DC, USA, 2007.

34. Tseng, W.C.; Kuo, Y.S.; Chen, J.W. An investigation into the effect of scour on the loading and deformation responses of monopile foundations. Energies 2017, 10, 1190. [CrossRef]

35. Reese, L.C.; Cox, W.R.; Koop, F.D. Analysis of laterally loaded piles in sand. In Offshore Technology in Civil Engineering Hall of Fame Papers from the Early Years; American Society of Civil Engineers: Reston, VA, USA, 1974; pp. 95-105.

36. Qi, W.G.; Gao, F.P.; Randolph, M.F.; Lehane, B.M. Scour effects on p-y curves for shallowly embedded piles in sand. Geotechnique 2016, 66, 648-660. [CrossRef]

37. Garrad Hassan and Partners Ltd. Bladed User Manual-Version 4.5; Garrad Hassan \& Partners Ltd.: Bristol, UK, 2013.

(C) 2018 by the authors. Licensee MDPI, Basel, Switzerland. This article is an open access article distributed under the terms and conditions of the Creative Commons Attribution (CC BY) license (http:/ / creativecommons.org/licenses/by/4.0/). 